\title{
GANGGUAN KOGNITIF PADA EPILEPSI
}

\author{
Andre Lukas ${ }^{1}$, Harsono $^{2}$, Astuti2 \\ ${ }^{1}$ Residen Neurologi Fakultas Kedokteran Universitas Gadjah Mada \\ ${ }^{2}$ Staf Pengajar Neurologi Fakultas Kedokteran Universitas Gadjah Mada
}

Korespondensi: drandrelukas@gmail.com

\begin{abstract}
ABSTRAK
Epilepsi merupakan salah satu penyakit dalam bidang neurologi yang insidensi dan prevalensinya terus meningkat. Penurunan fungsi kognitif yang sering ditemukan pada epilepsi sangat bergantung pada beberapa faktor antara lain etiologi, tipe bangkitan, sindrom epilepsi tertentu (epilepsi idiopatik umum, epilepsi absans, juvenile myoclonic epilepsy, epilepsi lobus temporal, epilepsi lobus frontal, dll), letak lesi atau fokus bangkitan, frekuensi dan durasi bangkitan, umur saat onset, adanya gangguan psikis lain seperti kecemasan dan depresi, serta obat antiepilepsi yang diminumnya.

Pada sebagian besar epilepsi, gangguan kognitif yang sering terjadi adalah gangguan pada atensi, psikomotor, visuospasial, memori dan fungsi eksekutif. Sindrom epilepsi tertentu seperti sindrom Ohtahara, West, Lennox Gastaut, CSWS (Continous Spike-Waves during Sleep Syndrome), dan Landau Kleffner Syndrome menunjukkan defisit kognitif yang lebih berat.

Manajemen epilepsi yang meliputi terapi farmakologis maupun terapi bedah berhubungan dengan munculnya gangguan kognitif pada penderita epilepsi. Walaupun obat anti-epilepsi generasi baru memiliki efek negatif terhadap fungsi kognitif yang lebih kecil dibandingkan dengan obat antiepilepsi generasi lama, namun penggunaannya termasuk dosis harus tetap hati-hati karena beberapa obat anti-epilepsi generasi baru juga berhubungan dengan penurunan fungsi kognitif yang nyata.
\end{abstract}

Kata Kunci: epilepsi, kognitif, patofisiologi, sindrom, manajemen 


\title{
COGNITIVE IMPAIRMENT IN EPILEPSY
}

\author{
Andre Lukas ${ }^{1}$, Harsono², Astuti2 \\ ${ }^{1}$ Neurology Resident of Medical Faculty University of Gadjah Mada \\ ${ }^{2}$ Neurology Staff of Medical Faculty University of Gadjah Mada \\ Correspondence: drandrelukas@gmail.com
}

\begin{abstract}
Epilepsy is a neurological disorder with increasing rate of incidence and prevalence. Cognitive impairment found in epilepsy is determined by some factors like etiology, seizure type, certain epilepsy syndrome (idiopathic generalized epilepsy, absance epilepsy, juvenile myoclonic epilepsy, temporal lobe epilepsy, frontal lobe epilepsy, etc), location of lesion or epileptic focus, frequency and duration, age of onset, anxiety or depression, and therapy.

In majority of epilepsy cases, cognitive impairment which frequently happens are deficits in attention, psychomotor speed, visuospatial function, memory and executive function. The worse cognitive function is found in some definite epilepsy syndrome like Ohtahara syndrome, West, Lennox Gastaut, CSWS (Continous SpikeWaves during Sleep Syndrome), and Landau Kleffner Syndrome.

Both pharmacologic and surgical therapy of epilepsy correlate with the incidence of cognitive impairment in epilepsy patient. Eventhough some novel antiepileptic drugs have a favourable effect than those found in old generation antiepileptic drugs, the decision in giving these drugs should be done carefully because some drugs still correlate with significant cognitive decline.
\end{abstract}

Keywords: epilepsy, cognitive, pathophysiology, syndrome, management 


\section{PENDAHULUAN}

Epilepsi merupakan "koleksi gangguan fungsi otak yang beraneka ragam" atau "badai listrik di otak". Bangkitan epilepsi adalah suatu tanda atau gejala sepintas yang disebabkan oleh aktivitas neuronal di otak yang bersifat sinkron dan berlebihan atau abnormal. Epilepsi adalah suatu gangguan fungsi otak yang dicirikan oleh kecenderungan predisposisi untuk menimbulkan bangkitan epileptik beserta konsekuensinya yang bersifat neurobiologik, kognitif, psikologik, dan sosial. ${ }^{1}$

Salah satu konsekuensi penting pada epilepsi adalah penurunan fungsi kognitif. Beberapa penelitian menunjukkan banyak pasien justru mengeluhkan penurunan fungsi kognitif lebih menyengsarakan dibandingkan epilepsi itu sendiri. ${ }^{2}$ Tinjauan pustaka ini bertujuan untuk memberikan gambaran mengenai manifestasi klinis, patofisiologi, dan faktor-faktor yang mempengaruhi munculnya gangguan kognitif pada epilepsi.

\section{DISKUSI}

Sebagian besar penderita epilepsi terutama penderita sindrom epilepsi tertentu akan mengalami gangguan kognitif. Prevalensi gangguan kognitif pada epilepsi berkisar antara 20-50\%. Gangguan kognitif dan perilaku yang dapat ditemukan pada penderita epilepsi dapat dipandang sebagai dampak langsung dari epilepsi itu sendiri atau justru sebagai efek dari terapi yang diberikan sehingga pemahaman interaksi antara epilepsi dan obatobatan yang digunakan dengan kejadian penurunan fungsi kognitif menjadi sangat penting. ${ }^{2}$

Epileptogenesis merupakan hal yang penting dalam pemahaman akan patogenesis munculnya gangguan kognitif pada epilepsi. Proses yang berkaitan dengan epileptogenesis dan bangkitan ini secara simultan dapat mempengaruhi aktivitas perkembangan otak yang normal seperti synaptic pruning, dendritic and axonal refinement, dan maturasi kanal ion dan reseptor. ${ }^{3}$

GABA merupakan neurotransmiter inhibitorik utama yang ada di otak dan reseptor $\mathrm{GABA}_{\mathrm{A}}$ memediasi inhibitory synaptic transmission yang paling cepat. Penggunaan benzodiazepin disinyalir akan menguatkan fungsi dari reseptor $\mathrm{GABA}_{\mathrm{A}}$ yang kemudian akan memutus pembentukan memori dan LTP (long term potentiation). $\mathrm{GABA}_{\mathrm{A}}$ reseptor juga memegang peran kunci sebagai regulator pada plastisitas kortikal dan hippocampal-dependent spatial learning. ${ }^{4,5}$

Perubahan pada neurotransmisi eksitatorik juga memiliki implikasi terhadap fungsi kognitif pasca epilepsi. Signal eksitatorik melalui reseptor NMDA dan AMPA berperan penting dalam proses LTP dan pembentukan memori.6,7,8 Hipoksia yang diinduksi oleh bangkitan epileptik akan menyebabkan efek pasca transkripsional yang cepat pada fosforilasi subunit reseptor AMPA (GLuR) yang kemudian akan menyebabkan perubahan fungsi eksitasi dari glutamat. ${ }^{9}$

Defisit kognitif yang terjadi pada epilepsi dibagi menjadi defisit kognitif permanen dan defisit kognitif dinamis. Defisit kognitif permanen dapat disebabkan oleh banyak faktor seperti trauma, hipoksia, kelainan genetik, sklerosis temporal mesial sebagai akibat dari status epileptikus atau suatu malformasi kortikal kongenital, sementara defisit dinamis dapat disebabkan oleh hal lain seperti akibat dari bangkitan itu sendiri, abnormalitas epileptiform interiktal, atau terapi antiepileptik yang digunakan. ${ }^{10}$

Interictal spikes (IIS) juga berhubungan dengan defisit kognitif 
yang terjadi dengan periode yang lebih singkat dibandingkan pada fase postictal. Interictal spikes (IIS) dapat menyebabkan gangguan singkat pada proses neuronal yang akan mendisrupsi proses yang sedang berjalan di otak sehingga menimbulkan transitory cognitive impairment. ${ }^{11}$

\section{Faktor-Faktor yang Mempengaruhi Munculnya Gangguan Kognitif pada Epilepsi}

Terdapat beberapa faktor yang mempengaruhi munculnya gangguan kognitif dan perilaku pada epilepsi antara lain etiologi epilepsi, tipe bangkitan, sindrom epilepsi, frekuensi dan durasi bangkitan, umur saat onset, ansietas, depresi, dan terapi epilepsi (Tabel 1).

Tabel 1. Faktor yang mempengaruhi fungsi kognitif pada epilepsi

\begin{tabular}{cl}
\hline No. & Faktor \\
\hline 1. & Etiologi \\
2. & Tipe bangkitan
\end{tabular}

3. Sindrom epilepsi

\section{Penjelasan}

- Etiologi epilepsi yang menimbulkan kerusakan struktur otak terbukti sangat berkaitan dengan munculnya gangguan kognitif pada epilepsi. ${ }^{12}$

- Epilepsi absans pada anak (childhood absance epilepsy) memiliki efek negatif minimal terhadap gangguan kognitif dibandingkan bangkitan konvulsif. 13

- Bangkitan umum tonik klonik memiliki dampak negatif terhadap fungsi kognitif yang lebih berat dibandingkan dengan epilepsi parsial, dan risiko terbesar ditemukan pada status epileptikus. ${ }^{13}$

- Pada epilepsi idiopatik umum, pasien hanya menunjukkan gangguan minor pada kapasitas intelektual global dan gangguan mayor pada domain atensi, psikomotor, visuospasial dan memori nonverbal dan tidak mempengaruhi kemampuan memori verbal dan bahasa. ${ }^{14}$

- Pada childhood absance epilepsy, diduga adanya keterlibatan pada jalur talamokortikal bilateral yang menyebabkan gangguan pada domain atensi, defective linguistic abilities, fungsi eksekutif, dan sosial. ${ }^{15}$

- Pada benign childhood epilepsy with centro temporal spikes (BECTS), disfungsi kognitif utama yang sering ditemukan adalah gangguan atensi, fungsi motorik, memori jangka pendek, visual dan persepsi. ${ }^{14}$

- Pada juvenile myoclonic epilepsy (JME) sering didapatkan adanya sindrom diseksekutif frontal. Gangguan kognitif utama yang sering dijumpai pada JME adalah masalah dalam reasoning, pembentukan konsep, fleksibilitas dan kecepatan mental, dan masalah pada memori kerja visual. 16,17

- Epilepsi lobus temporal hampir mempengaruhi hampir semua aspek kognitif antara lain atensi, bahasa, praksis, fungsi eksekutif, judgement, 
insight, dan problem solving. ${ }^{18,19}$ Namun, dari semuanya itu, aspek kognitif yang paling dominan yang ditemukan pada epilepsi lobus temporal adalah gangguan memori. ${ }^{20}$ Gangguan spesifik kategorik pada semantic word fluency menunjukkan kecurigaan pada epilepsi lobus temporal lateral. Berbeda dengan epilepsi lobus temporal kiri, epilepsi lobus temporal sisi kanan baik yang disertai atrofi/sklerosis hipokampal menunjukkan penurunan fungsi pada memori figural/visual. ${ }^{21}$

- Pada epilepsi lobus frontal sering didapatkan masalah pada atensi, memori jangka pendek dan jangka panjang, fleksibilitas mental, fungsi inhibisi, antisipasi, perencanaan dan pengambilan keputusan. ${ }^{21}$

- Pada epilepsi lobus parietal dan oksipital atau yang dikenal sebagai sindrom epilepsi posterior sangat jarang dijumpai penderita yang mengalami gejala klasik seperti afasia, aleksia, agrafia, akalkulia, agnosia, ataksia optik, neglect. Gangguan kognitif difus dan retardasi mental justru lebih prominen terutama pada epilepsi lobus parietalis. ${ }^{22}$

- Sindrom Ohtahara dan West adalah salah satu sindrom epilepsi pada anak. Dalam fase awal kehidupan, kemampuan yang paling pertama muncul adalah atensi visual dan visuo-auditorysocial competences. Tanda interiktal yang dapat dilihat adalah hilangnya senyuman dan kontak visual pada pasien. Bila bangkitan pada sindrom ini tidak ditangani dengan baik, maka penderita sindrom ini akan berkembang menjadi autistik, yang akan berlanjut seumur hidupnya. ${ }^{23}$

- Penyebab penurunan fungsi kognitif pada sindrom Lennox Gastaut adalah multifaktorial antara lain frekuensi bangkitan yang tinggi, trauma kepala berulang yang terjadi saat epileptic drop attack, continous SW discharges selama fase tidur, politerapi, dan lain-lain. ${ }^{24}$

- Gangguan kognitif yang sering dijumpai pada CSWS adalah gangguan bahasa bila abnormalitas berpusat pada lobus temporal, dan gangguan tingkah laku, hiperkinesia, dan psikosis pada penderita dengan fokus di lobus frontal atau clear-cut anterior predominance of the discharges. ${ }^{24}$

- Pada sindrom Landau Kleffner (LKS) ditemukan pada anak yang sebelumnya sehat kemudian mengalami agnosia verbal auditori, regresi kemampuan bahasa, kejang, dan EEG epileptiform dengan ESES. ${ }^{24}$ 
4. Frekuensi
bangkitan

5. Durasi bangkitan

6. Umur saat onset

7. Faktor psikis
- Terdapat korelasi negatif antara frekuensi bangkitan umum tonik klonik dan performa kognitif pada pemeriksaan neuropsikologis. ${ }^{25}$

- Durasi penyakit berkorelasi positif dengan penurunan fungsi kognitif pada penderita epilepsi. ${ }^{21,26}$

- Sebagian besar penelitian yang dilakukan mengindikasikan korelasi antara semakin muda usia seseorang saat onset epilepsi dengan semakin buruknya fungsi kognitifnya. ${ }^{27}$

- Prevalensi ansietas dan depresi pada penderita epilepsi mencapai 4-5 kali lebih tinggi dibandingkan pada populasi umum. ${ }^{28}$ Ansietas berhubungan dengan disfungsi memori episodik. ${ }^{29}$ Depresi berhubungan dengan gangguan atensi, memori, kecepatan berpikir dan psikomotor, serta fungsi eksekutif. 30
Selain hal-hal yang telah dijelaskan sebelumnya, terapi epilepsi baik terapi farmakologis maupun nonfarmakologis terbukti sangat mempengaruhi munculnya gangguan/penurunan fungsi kognitif pada penderita epilepsi. Bromida, benzodiazepin dan fenobarbital memiliki efek negatif yang lebih besar dibandingkan dengan fenitoin, karbamazepin, atau asam valproat walaupun fenitoin, karbamazepin, dan asam valproat juga memiliki efek negatif terhadap fungsi kognitif. ${ }^{31}$

Obat-obatan antiepilepsi yang memiliki mekanisme aksi pada kanal natrium memiliki efek samping terhadap fungsi kognitif yang lebih kecil, di mana risiko yang lebih besar terkait dengan obat-obatan yang bersifat GABAergik. Obat-obatan yang memblok kanal natrium seperti lamotrigin dan oxcarbazepin memiliki efek positif terhadap kognitif yakni peningkatan kecepatan belajar dan psikomotor. Efek ini lebih jelas terlihat pada obat yang spesifik bekerja pada reseptor $N$-methyl-D-Aspartic Acid (NMDA). Obat-obatan antiepileptik memiliki efek psikotropik positif dan negatif pada kognisi dan perilaku. Obat-obatan antiepileptik generasi lama seperti fenobarbital, fenitoin, karbamazepin, dan asam valproat lebih sering dikaitkan dengan problem kognitif dibandingkan dengan obat antiepilepsi generasi baru seperti lamotrigin, gabapentin, levetirasetam, topiramat, zonegran, d11. ${ }^{32,33}$

Domain utama yang seringkali terkena dampak negatif dari penggunaan obat anti epilepsi adalah atensi dan fungsi eksekutif, namun domain memori dan bahasa juga dapat terlibat dalam beberapa studi yang pernah dilaporkan. ${ }^{31}$ Efek obat antiepilepsi terhadap fungsi kognitif dapat dilihat pada Tabel 2 .

Tabel 2. Efek obat antiepilepsi terhadap fungsi kognitif

\begin{tabular}{lll}
\hline No. & Obat Anti Epilepsi & Dampak pada Fungsi Kognitif \\
\hline 1. & Fenitoin & $\begin{array}{l}\text { Penurunan pada fungsi memori, kecepatan } \\
\text { berpikir, dan psikomotor. }{ }^{34}\end{array}$ \\
2. & Karbamazepin & $\begin{array}{l}\text { Penurunan pada memori dan performa } \\
\text { visual task. } 34\end{array}$
\end{tabular}


3. Asam Valproat

4. Lamotrigin

5. Gabapentin

6. Levetiracetam

7. Topiramat
Penurunan pada IQ, memori, dan komunikasi verbal. ${ }^{27}$

Efek positif pada fungsi kognitif, memiliki efek mood stabilizer. ${ }^{35}$

Memiliki efek psikotropik positif, tidak ditemukan adanya gangguan memori ataupun psikomotor pada penggunaan gabapentin. ${ }^{32}$

Berdampak positif terhadap performa kognitif karena memiliki efek arousal activating. ${ }^{36}$

Penurunan verbal IQ, verbal fluency, verbal learning, dan atensi. ${ }^{25}$
Terapi bedah merupakan pilihan terapi yang cukup menjanjikan pada pasien dengan epilepsi simtomatik fokal dan digunakan untuk menangani epilepsi refrakter/farmakoresisten. Terapi bedah sendiri memiliki dampak positif dan negatif terhadap fungsi kognitif. Risiko terjadinya penurunan fungsi kognitif pasca operasi sangat bergantung pada karakteristik masingmasing pasien. ${ }^{37}$

\section{KESIMPULAN}

Pada sebagian besar epilepsi, gangguan kognitif yang sering terjadi adalah gangguan pada atensi, psikomotor, visuospasial, memori dan fungsi eksekutif. Sindrom epilepsi tertentu seperti sindrom Ohtahara, West, Lennox Gastaut, CSWS (continous spike-waves during sleep syndrome), dan Landau Kleffner menunjukkan defisit kognitif yang lebih berat.

Manajemen epilepsi yang meliputi terapi farmakologis maupun terapi bedah berhubungan dengan munculnya gangguan kognitif pada penderita epilepsi. Walaupun obat anti-epilepsi generasi baru memiliki efek negatif terhadap fungsi kognitif yang lebih kecil dibandingkan dengan obat antiepilepsi generasi lama, namun penggunaannya termasuk dosis harus tetap hati-hati karena beberapa obat anti-epilepsi generasi baru juga berhubungan dengan penurunan fungsi kognitif yang nyata.

\section{DAFTAR PUSTAKA}

1. Fisher R, van Emde Boass W, Blume W, et al. Epileptic Seizures and epilepsy: definitions proposed by the International League Against Epilepsy (ILAE) and the International Bureau for Epilepsy. Epilepsia. 2005;46(4): 470-472.

2. Aldenkamp AP. Cognitive Impairment in Epilepsy: State of Affairs and Clinical Relevance. Seizure. 2006;15:219-220.

3. Porter BMM, Brooks-Kayal A. Fate of newborn dentate granule cells after early life status epilepticus. Epilepsia. 2004;45:13 $-19$.

4. Fagiolini M, Fritschy JM, Low $\mathrm{K}$, Mohler H, Rudolph U, Hensch TK. Specific GABAA circuits for visual cortical plasticity. Science. 2004; 303: 1681-1683.

5. Rudolph U, Mohler H. Analysis of GABAA receptor function and dissection of the pharmacology of benzodiazepines and general anesthetics through mouse genetics. Annu Rev Pharmacol Toxicol. 2004; 44:475 $-498$. 
6. Mongillo G, Amit DJ, Brunel N. Retrospective and prospective persistent activity induced by Hebbian learning in a recurrent cortical network. Eur J Neurosci. 2003; 18:20112024.

7. Riedel G, Platt B, Micheau J. Glutamate receptor function in learning and memory. Behav Brain Res. 2003;140:1-47.

8. Schmitt WB, Sprengel R, Mack V, Draft RW, Seeburg PH, Deacon RM, Rawlins JN, Bannerman DM. Restoration of spatial working memory by genetic rescue of GluR- Adeficient mice. Nat Neurosci. 2005;8:270-272.

9. Rakhade SN, Zhou C, Aujla PK, Fishman R, Sucher NJ, Jensen FE. Early alterations of AMPA receptors mediate synaptic potentiation induced by neonatal seizures. J Neurosci. 2008; 28:7979-7990.

10. Kleen JK, Scott RC, Santini PPL, Holmes GL. Jasper's Basic Mechanisms of the Epilepsies [Internet]. 4th edition. United States of America: Oxford University Press; 2012.

11. Binnie CD. Cognitive impairment during epileptiform discharges: is it ever justifiable to treat the EEG.Lancet Neurol. 2003;2:725-730.

12. Cendes F. Progressive hippocampal and extra hippocampal atrophy indrug resistant epilepsy. Curr Opin Neurol. 2005;18:173-177.

13. Lezak M, Howieson D, Loring D. Neuropsychological Assessment. United States of America: Oxford University Press; 2004.

14. Hommet C, Sauerwein HC, De Toffol B, Lassonde M. Idiopathic epileptic syndromes and cognition. Neurosci Biobehav Rev. 2005.
15. Hermann B, Seidenberg $M$, Sager M, et al. Growing old with epilepsy: the neglected issue of cognitive and brain health in aging and elder persons with chronic epilepsy. Epilepsia. 2008;49:731-740.

16. Linn JJ, Mula M, Hermann BP. Uncovering the neurobehavioural comorbidities of epilepsy over the lifespan. Lancet. 2012;380: 1180-1192.

17. Sonmez F, Atakli D, Sari H, Atay T, Arpaci B. Cognitive function in juvenile myoclonic epilepsy. Epilepsy Behav. 2004 Jun 5(3); 329-336.

18. Hermann BP, Seidenberg $M$, Dow C, Jones J, Rutecki P, Bhattacharya A, et al. Cognitive prognosis in chronic temporal lobe epilepsy. Ann Neurol. 2006; 60(1):80-87.

19. Keary TA, Frazier TW, Busch $\mathrm{RM}$, Kubu CS, Iampietro M. Multivariate neuropsychological prediction of seizure lateralization in temporal epilepsy surgical cases. Epilepsia. 2007; 48(8):1438- 1446.

20. Lee TM, Yip JT, Jones-Gotman M. Memory deficits after resection from left or right anterior temporal lobe in humans: a meta-analytic review. Epilepsia. 2002;43(3):283-291.

21. Elger CE, Helmstaedter C, Kurthen M. Chronic epilepsy and cognition. Lancet Neurol. 2004 Nov; 3(11): 663-672.

22. Kasowski HJ, Stoffman MR, Spencer SS, Spencer DD. Surgical management of parietal lobe epilepsy. Adv Neurol. 2003;93:347- 356.

23. Turati C, Valenza E, Leo I, Simion F. Three-month-olds' visual preference for faces and its underlying visual processing 
mechanisms. J Exp Child Psychol. 2005;90:255-273.

24. Rijckevorsel K. Cognitive Problems Related to Epilepsy Syndromes, Especially Malignant Epilepsies. Seizure. 2006;15;227 $-234$.

25. Aldenkamp AP, Bodde $\mathrm{N}$. Behaviour, Cognition and Epilepsy. Acta Neurologica Scandinavica. 2005;112 (suppl 182): 19-25.

26. Jokeit H, Ebner E. Long-term effects of refractory temporal lobe epilepsy on cognitive abilities: A cross sectional study. J Neurol Neurosurg Psychiatry. 1999;67:44-50.

27. Desai J. Epilepsy and Cognition. J Pediatr Neurosci. 2008; Vol.3 Jan- Jun.

28. McCagh J, Fisk J, Baker G . Epilepsy, psychosocial and cognitive Iunctioning. Epilepsy Research. 2009;86: 1- 14 .

29. Airaksinen E, Larsson M, Forsell Y. Neuropsychological Functions in Anxiety Disorders in Population- Based Samples: Evidence of Episodic Memory Dysfunction. Journal of Psy chiatric Research. 2005;39:207214.

30. Gualtieri C,Johnson L, BenedictK. Neurocognition in depression: patients on and off medication versus healthy controlled subjects. Journal of Neuropsy chiatry and Clinical Neuro sciences. 2006;18:217 225.
31. Witt JA, Helmstaedter C. Monitoring the cognitive effects of antiepileptic pharmacotherapy - approaching the individual patient. Epilepsy Behav. 2013;26:450-456.

32. Loring DW, Meador KJ. Cognitive side effects of antiepileptic drugs in children. Neurology. 2004; 62:872-877.

33. Ortinski P, Meador KJ. Cognitive side-effects of antiepileptic drugs. Epilepsy Behav. 2004;5:S60-65.

34. Seidel WT, Mitchell WG. Cognitive and Behavioural Effects of Carbamazepine in Children: Data From Benign Rolandic Epilepsy.J Child Neurol. 1999; November;14(11):716-723.

35. Gajwani P, Forsthoff A, Muzina D, Amann B, Gao K, Elhaj O, Calabrese JR, Grunze H. Antiepileptic drugs in mooddisordered patients. Epilepsia. 2005; 46(Supp1 4):38-44.

36. Lagae L. Cognitive side-effects of anti-epileptic drugs: the relevance in childhood epilepsy. Seizure. 2006;15:235-241.

37. Sanyal SK, Chandra PS, Gupta $\mathrm{S}$, et al. Memory and intelligence outcome following surgery for intractable temporal lobe epilepsy: relationship to seizure outcome and evaluation using a customized neuropsychological battery. Epilepsy \& Behavior. 2005;6:147- 155. 